\title{
Archimedes between legend and fact
}

\author{
Lucio Russo
}

Published online: 3 August 2013

(c) Centro P.RI.ST.EM, Università Commerciale Luigi Bocconi 2013

\begin{abstract}
The figure of Archimedes that most are familiar with is depicted in the works of authors such as Vitruvius and Plutarch, who lived centuries after his death and transmit an image of the scientist that is deformed by legend. This paper re-examines what is actually known about the life of Archimedes and his personality.
\end{abstract}

Keywords Archimedes · History of science · History of technology $\cdot$ Diodorus Siculus · Polybius . Pliny the Elder · Cicero · John Zonaras · John Tzetzes · Titus Livius · Plutarch · Galen · Simplicius

Probably no scientist has ever occupied a larger place in the collective imagination than Archimedes (Fig. 1). The figure of Archimedes that most are familiar with is depicted, however, in the works of authors such as Vitruvius and Plutarch, who lived centuries after his death and transmit an image of the scientist that is deformed by legend, one that already by their day at least partly shrouded his memory, and one that they themselves contributed to, at least in part. It is thus useful to re-examine what we really know about the life of Archimedes and his personality.

There are few biographical facts that are absolutely certain. There is no doubt that Archimedes was a Syracusan, and that he died during the Roman sack of Syracuse in 212 в.с. His date of birth is much less certain. It is thought that he was born in 287 B.c.-in fact, this year we celebrate the twenty-third centenary of his birth - but the only author who gives this date is the Byzantine John Tzetzes, of the

L. Russo ( $\square)$

Dipartimento di Matematica, Università di Roma "Tor Vergata",

Via della Ricerca Scientifica, 1, 00133 Rome, Italy

e-mail: russo@mat.uniroma2.it twelfth century, according to whom Archimedes died at the age of 75 [Chiliades, II, 108]. It is possible that Tzetzes had reliable sources at his disposal that we do not know about, but it might also be that he (or his source) wished only to quantify the fact, mentioned by several authors, that he died when he was old. We will see that we have good reasons not to place too much faith in his testimony. The news that he was the son of the astronomer Phidias, given in many texts as certain, derives from a passage in Sand Reckoner by Archimedes himself, incomprehensible in the manuscripts (Arenario, II, 136-137, [Mugler 1970-1972 $3]$ ), which the philologist Friedrich Blass in 1883 emended, conjecturing that it contained the words $\Phi_{\varepsilon l} \delta i \alpha$ $\delta \grave{\epsilon} \tau o \tilde{u}$ $\dot{\alpha} \mu o \tilde{u} \pi \alpha \tau \rho \grave{o} \varsigma$ (my father Phidias). Since the context regards an estimate of the ratio between the dimensions of the sun and the moon, if the amendment is correct, the hypothetical father Phidias should presumably have dealt with astronomy on at least one occasion, but no other source cites an astronomer by that name.

I don't believe there is any reason to doubt Plutarch's statement (Vita Marcelli, 14, 7) that Archimedes, in addition to being friends with, was also a relative ( $\sigma v \gamma \gamma \varepsilon v \grave{\eta} \varsigma)$ of the tyrant of Syracuse Hieron I, although to some that information seems to contradict a passage of Cicero. ${ }^{1}$

It is also certain that Archimedes spent time in Alexandria. Diodorus Siculus (Bibliotheca historica, V, 37, 3) tells us that Archimedes invented the screwpump when he was in Egypt. Moreover, the terms used by Archimedes in

\footnotetext{
${ }^{1}$ Cicero (Tusculanae disputationes, $\mathrm{V}, 23$ ) says that he wants to contrast the life of Dionysius I of Syracuse with that of a man who is humble and common (humilem homunculum) from the same city: Archimedes. It does not seem to me that this passage must necessarily be interpreted as a reference to Archimedes' humble origins; Cicero might only have wished to underline the distance between a sovereign and a private citizen.
} 


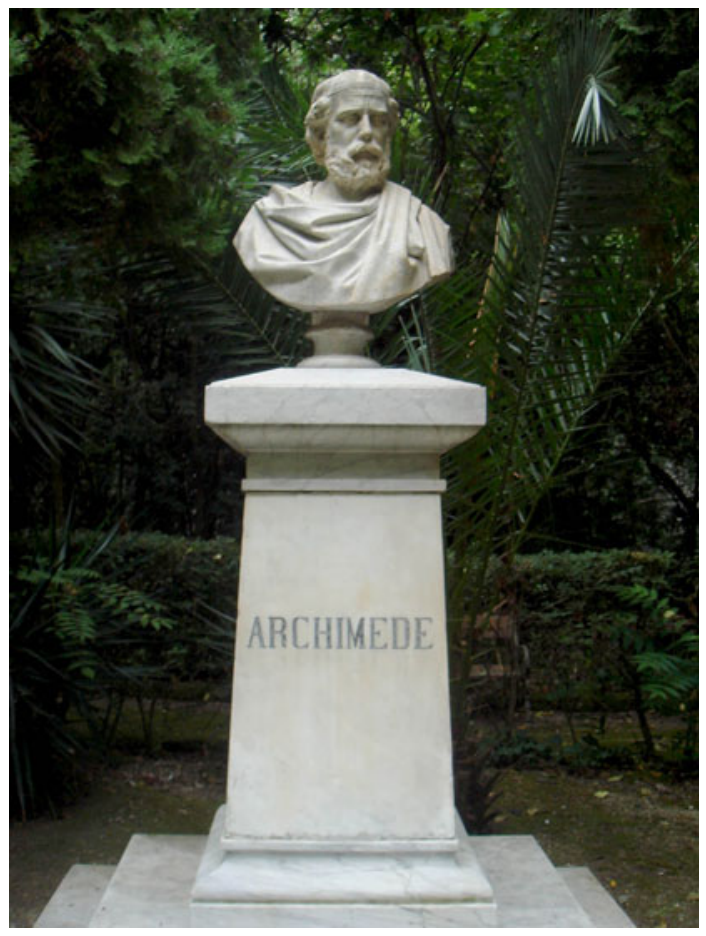

Fig. 1 Bust of Archimedes by Luciano Campisi (1859-1953). Photo: Giovanni Dall'Orto

lamenting the death of Conon of Samos (De sphaera et cylindro, I, 9; De lineis spiralibus, II, 8), who was active in Alexandria, lead us to presume that he had known him personally.

The biographical facts on which the sources dwell the most regard Archimedes' contribution to the defence of Syracuse during the Roman siege of 212 B.C. and his death during the sack of that city. The best source for the siege, due both to his nearness to the events and for his general reliability, is Polybius (Historiae, VIII, chaps. 3-7). In his account, the historian describes war machines conceived by Archimedes, and in particular the various kind of weapons for launching projectiles and the manus ferrea ( $\chi \varepsilon i \rho$ $\sigma \iota \delta \eta \rho \tilde{\alpha})$ or claw, manoeuvred from inside the wall, used to overturn Roman ships as they drew near. Polybius (Historiae, VIII, 7) underlines the importance of Archimedes' contribution to the defence of the city, writing among all else:

Such a great and marvellous thing does the genius of one man show itself to be when properly applied to certain matters. The Romans at least, strong as they were both by sea and land, had every hope of capturing the town at once if one old man of Syracuse were removed; but as long as he was present, they did not venture even to attempt to attack in that fashion in which the ability of Archimedes could be used in the defence [Polybius 1922 6, III, 462-463].

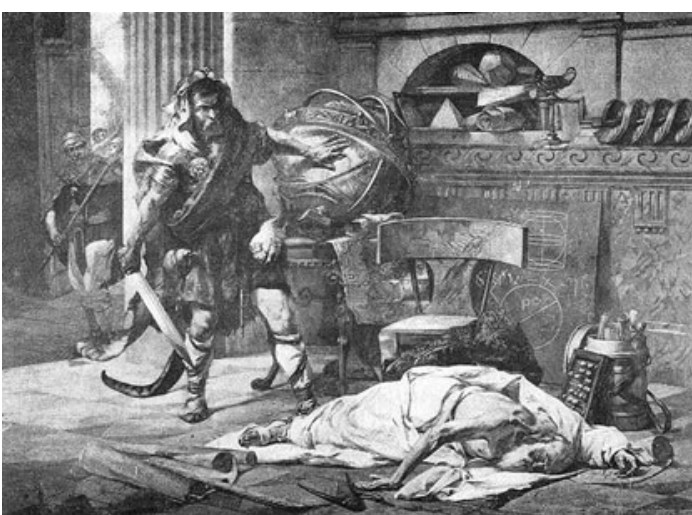

Fig. 2 The death of Archimedes from an illustration from Beacon Lights of History, after a painting by Edouard Vimont (1846-1930)

In Polybius, who wrote in the second century B.C., there is no trace of the episodes during the siege that most nourished the legend of Archimedes: the construction of the burning mirrors and the circumstances of his death (Fig. 2).

At the time it must have seemed completely natural that Archimedes did not survive the attack on the city. The idea that the commander of the Romans, Marcellus, lamented the death of the elderly scientist appears only a century later and for the first time in a writing of Cicero (In Verrem, II, 4, 131), who was also the first to recount how, when the Romans conquered Syracuse, Archimedes was so absorbed in the study of geometric figures that he didn't notice it $(D e$ finibus, V, 50). It is well known that Cicero also boasted of having found Archimedes' tomb when he was quaestor in Sicily: he claims to have recognised it by the drawing of a sphere inscribed in a cylinder etched into it. The Syracusans themselves had told him that that etching indicated the tomb of Archimedes, which, moreover, was located where one might have expected, that is, in the city cemetery. And yet many believed Cicero's strange boast.

Gradually, as the facts faded into the past, the details of Archimedes' death were embellished and the Romans' responsibility for it was played down. In Pliny the Elder's Natural History appears for the first time the information that Archimedes was killed in violation of Marcello's explicit orders to spare him (Naturalis Historia, VII, 125). Valerius Maximus (Factorum et dictorum memorabilium libri IX, 8.7, ext 7) also tells of Archimedes' last words, which asked his assassin not to ruin the geometric figure he had just drawn. Around 100 A.D. Plutarch not only wrote of the death of the scientist, giving various alternate versions of the circumstances (Vita Marcelli, 19, 4-5), but also seems to know other details of Marcellus's behaviour, which appears to be even more laudable. The Roman commander, encountering Archimedes' killer, is said to have turned his gaze away in a sign of disdain, and to have 
wished to honour the scientist's relatives (Vita Marcelli, $19,6)$.

In the Byzantine authors John (Ioannes) Zonaras and John Tzetzes the details become even more precise. They even knew the last two sentences pronounced by Archimedes before he died ([10], II, 264, 24-265, 2) - even though the two versions don't agree even partially. In the work by Tzetzes in particular there are new elements. Not only does he maintain that Archimedes attempted to defend himself, asking for a weapon, but he also conjectures that Marcellus had the killer executed (Chiliades, II, 134-155). These details, of course fanciful, cast much doubt on the reliability of Tzetzes report of Archimedes' age.

The invention of the details of Archimedes' death continued up until recent periods. According to many books (and innumerable Internet sites), Archimedes words to the Roman soldier who was about to kill him were Noli turbare circulos meos (this phrase is even repeated in the relatively recent book by Dijksterhuis [1987] [1]). Sometimes it is

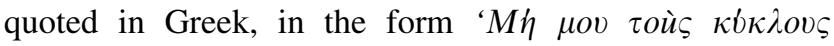
$\tau \dot{\alpha} \rho \alpha \tau \tau \varepsilon$. Nevertheless, it seems clear that the Greek expression was translated from Latin, and not the other way around. In any case, no Greek, Latin or Byzantine author quotes it, either in Greek or in Latin. It remains to be discovered who is the first to have introduced the habit of quoting it, and if among other things he intended the vaguely obscene allusion with which it is often cited.

Likewise, the testimonies of the episode of the burning mirrors grow and become more detailed with the passing of time. Polybius, Titus Livius (who provides a more succinct account of the siege of Syracuse, Ab urbe condita libri CXLII, XXIV, 34) and Plutarch (who describes the siege in the Vita Marcelli cited earlier) say nothing of it. The first mentions of Roman ships set afire from a distance thanks to devices invented by Archimedes appears in the second century A.D., in one passage from Lucian (Ippia, 2) and one from Galen (De temperamentis, III, 2) ${ }^{2}$ Neither of the two, however, speak of mirrors, and the most plausible interpretation is that they intended to refer to the launching of incendiary substances. The first clear reference to burning mirrors dates to the sixth century and is due to Anthemius of Tralles, who cites the episode as unanimously accepted

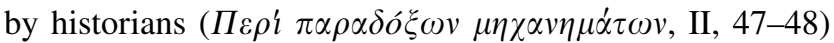
and then, in the same work, proposes a conjectural reconstruction of the form and construction of the mirrors ( $\Pi \varepsilon \rho \hat{\imath}$ $\pi \alpha \rho \alpha \delta \delta \xi \omega \nu \mu \eta \chi \alpha v \eta \mu \dot{\alpha} \tau \omega v$, III, 49-50). In the twelfth century, Zonaras (Epitome historiarum, [Dindorf] vol. II, 263, 2-8) and Tzetzes (Chiliades, II, 121-131), authors

\footnotetext{
${ }^{2}$ For a long time the passage of Galen was interpreted as the first testimony of the use of the mirrors to set Roman ships on fire. That interpretation, however, was based on the attribution of the meaning of 'burning mirror' to the Greek term $\pi v \rho \varepsilon i o v$, which might also refer to incendiary substances.
}

already mentioned, describe in detail the mirrors of Archimedes. Their source-particularly in the case of Tzetzes-seems to be Anthemius, but details that in Anthemius were explicitly part of the conjectural reconstruction (for example, the hexagonal shape of the central mirror) are by now presented as facts.

The development of the testimonies that we have described renders highly unlikely the use of mirrors in war, but this does not mean we must necessary deduce that they were only legend. The description of parabolic mirrors by Diocles, which we have in an Arabic translation, ${ }^{3}$ which contains a demonstration of the focal property of the parabola, is proof that in Antiquity these devices were effectively designed, and there is no reason why they might not have been constructed. Archimedes, who was an expert in parabolas and paraboloids (which he also used in his treatise On Floating Bodies), had written a voluminous treatise on Catoptrica (that is, on mirrors) in which, according to Apuleius (Apologia, 16), were also found descriptions of mirrors that, when placed facing the sun, were capable of igniting flammable objects. If this treatise was the unacknowledged source for Diocles, the legend of the ships set afire with burning mirrors might have been created from the mingling of the memory of Archimedes' design for such mirrors (perhaps conceived as a useful substitute for wood) with that of his contrivances with which the Syracusans launched incendiary substances.

In the other episodes that nourished the legend of Archimedes it is likewise generally possible to find a kernel of truth deformed by tradition. One of the most famous is the phrase 'Give me a lever and a fulcrum on which to place it, and I shall move the world!', cited, with a few variations, by several authors. The first was Plutarch (Vita Marcelli, 14, 7-9), followed in the fourth century by Pappus (Collectio, VIII, 1060, 1-12 [Hultsch 1876 3]), in the sixth century by Simplicius (In Aristotelis Physicorum libros commentaria, 1110, 2-5 [1882] [9] and Olympiodorus (In Platonis Alcibiadem, 191, 14-18), and in the twelfth century by Tzetzes (Chiliades, II, 132-133). In Plutarch we find only a paraphrasing of the concept expressed, while the citation becomes apparently literal in Pappus. In the Byzantine period is added a touch of realism, with the phrase given in the dialect of Syracuse, as though it had just been heard. All of the authors mentioned connect the words of Archimedes to the invention of a machine for hoisting weights. However, their opinions differ on exactly what type of machine it was: according to Plutarch it was a polyspaston, for Pappus and Olympiodorus it was a baroulcus, while for Simplicius it was a charistion. Tzetzes does not mention any direct

\footnotetext{
${ }^{3}$ The best translation into a Western language is found in Rashed [8].
} 
relationship to the statement, but just before he had mentioned a trispaston. All of the authors, except for Tzetzes, the most recent, clarify the logical nexus between the statement and the Archimedean theory of mechanics, which makes it possible to design machines with a high degree of mechanical advantage (that is, a favourable ratio between weight lifted and force acting). The logical relationship is particularly clear in the passages of Pappus and Simplicius. For example, Pappus writes:

In this way we learn how to move a given weight with a given force. It is said that this section of Mechanics is one of Archimedes' discoveries and that when he discovered it he said, "Give me a place to stand on, and I will move the world for you!" Heron of Alexandria gave a most clear exposition of this operation ...In his book "Barulcus", however, he explains how a given weight is moved by a given power ...[Pappus 1970 5, Book 8, sect. 19].

Plutarch alone collocates the famous phrase in relation with the likewise famous experimental demonstration in which Archimedes pushed a ship into the sea by himself, thanks to a machine that he had designed. The episode of the ship is, however, also told by Proclus (In primum Euclidis Elementorum librum commentarii, 63 [Proclus 1873 7]), who relates it to the launch of the ship Syracusia. Athenaeus (Deipnosophistae, V, 207b), our essential source about this ship, speaks of the launch omitting fanciful details such as that of the machine operated by a single man, but underlining Archimedes' essential contribution. The most recent author, Tzetzes, recounts the episode of the ship without placing it in relation with the Syracusia (Chiliades, II, 110-111), but adding of his own initiative that Archimedes could have pushed it into the sea with only his left hand.

The episode of Archimedes in which he intuits the way to expose the fraud relative to the crown of Hiero II while bathing is so famous that it doesn't need to be told in detail. The image of Archimedes who, elated by his discovery, jumps out of the bath and runs nude through the city crying, 'Eureka! Eureka!' is perhaps the most popular of all those told about the great Syracusan scientist. The story is told succinctly in Plutarch (Non posse suaviter vivi secundum Epicurum, 1094 B-C) and Proclus (In primum Euclidis Elementorum librum commentarii, 63 [Proclus 1873 7]) but the version that has taken root in the collective imagination is the longer version transmitted by Vitruvius (De Architectura, IX, Introduction, 9-12). Several points should be underlined. First of all there is an abyss between Vitruvius's account and the depth of Archimedean hydrostatics as it appears in his treatise On Floating Bodies. In the second place, it should be noted that not even on the episode of the crown, which is certainly marginal, is the account of Vitruvius the most reliable. A much more serious description of the procedure used by Archimedes to unmask the goldsmith, if for no other reason than it actually uses Archimedean hydrostatics, is contained in an anonymous work that is much less well known, dating to about 400 A.D. (Carmen de ponderibus et mensuris, 125-155). As is always the case, here too the better-known account is not the most reliable, but is the one that is so superficial that it requires no effort on the part of the reader.

Archimedes has often been presented as a scientist who was uninterested in the concrete world and so lost in abstract considerations and theories that he completely lost touch with reality. This image, which has resulted in an archetype adapted to later scientists as well, was transmitted above all by Plutarch, who relates more than once that the servants had to drag forcefully Archimedes to bathe, while he continued to draw geometric figures where he could, on his own stomach if nothing else was available (Vita Marcelli, 17, 11-12; Non posse suaviter vivi secundum Epicurum, 1094 B; An seni respublica gerenda sit, 786C). Plutarch also insists on his lack of interest in the applications of his own theories, since he would have considered this only a vulgar by-product of pure science, the only thing that genuinely interested him (Vita Marcelli, 14, 3-4; 17, 3-4). It is amazing that for a long time Archimedes' attitude towards the applications of science were deduced from the acritical acceptance of the opinion of Plutarch: a polygraph who lived centuries later, in a cultural climate that was completely different, certainly could not have known the intimate thoughts of the scientist. On the other hand, the dedication with which Archimedes developed applications of all kinds is well documented: of catoptrica, as Apuleius tells in the passage already cited (Apologia, 16), of hydrostatics (from the design of clocks ${ }^{4}$ to naval engineering: we know from Athenaeus (Deipnosophistae, V, 206d) that the largest ship in Antiquity, the Syracusia, was constructed under his supervision), and of mechanics (from machines to hoist weights to those for raising water and devices of war).

In the final analysis, the testimonies regarding Archimedes should be taken with a grain of salt, and are certainly more useful for extracting factual information that for deriving psychological information. The little that we really know about Archimedes' personality we can deduce from his works and from the facts documented. What emerges is a personality extraordinary for its total control of all aspects of a unified science, one which had not yet been divided up into mathematics, physics and technology:

\footnotetext{
4 A treatise on the construction of water-clocks, conserved in three Arabic manuscripts, has been published in an English translation by Hill [2].
} 
from the choice of the postulates to technological applications. We can, however, discern some human traits of the scientist: from the profound intellectual honesty shown in the treatise The Method, in which he decides to explain not only his results but also the procedures that he followed to discover them, a subtle sense of humour and probably an ironic attitude towards the scientists of Alexandria, which emerges more than once. The 'cattle problem', which we know in the form of an epigram, is practically unsolvable (the minimum solution is given by numbers with 206,545 digits) but it is proposed as a proof to judge the level of mathematical proficiency: the irony is suggested above all by the correspondent whom Archimedes wished to put to the test: the great Eratosthenes, the leader of the Alexandrian scientists. ${ }^{5}$ In another case, Archimedes is responsible for a genuine hoax. Tired of hearing it said that the results he had announced had also been obtained independently by other scientists, Archimedes communicated to his Alexandrian correspondents that he had solved a series of problems: only some time later (when, presumably, his rivals had claimed credit for the same results as independently theirs), he revealed that the 'solutions' that he had announced were completely wrong (De lineis spiralibus, 8-10 [Mugler 1970-1972 4]). ${ }^{6}$ It would be very interesting to know the identity of the victims of the hoax and what their reactions were.

Translated from the Italian by Kim Williams

\section{References}

1. Dijksterhuis, E.J.: Archimedes. Princeton University Press, Princeton (1987)

2. Hill, D.R.: On the construction of water-clocks: Kitab Arshimidas fi'amal al-binkamat. Turner \& Devereux, Baltimore (1976)

3. Hultsch, F.O. (ed.): Pappi Alexandrini collectionis quae supersunt. 3 vols. Apud Weidmannos, Berlin (1876)

4. Mugler, C.: Archimède. 4 vols. Les Belles Lettres, Paris (1970-1972)
5. Pappus Alexandrinus: Mathematical Collection, Book 8, D. Jackson (trans.). http://archimedes.mpiwg-berlin.mpg.de/cgi-bin/toc/toc.cgi? page $=23$; dir=pappu_coll8_095_en_1970;step=textonly (1970)

6. Polybius: The Histories, 6 vols. W. R. Paton, trans. Loeb Classical Library, Harvard University Press, Cambridge (1922-1927)

7. Proclus: In primum Euclidis Elementorum Librum commentarii. Friedlin, G. (ed.). B.G. Teubner, Leipzig (1873)

8. Rashed, R.: Les Catoptriciens Grecs. Tome I. Les Miroirs ardents. Texte établi, traduit et commenté par Roshdi Rashed. Les Belles Lettres, Paris (2002)

9. Simplicius: In Aristotelis Physicorum libros quattuor priores commentaria. Diels, H. (ed.) G. Reimeri, Berlin (1882)

10. Zonaras, I.: Epitome historiarum, 6 vols. L.A. Dindorf (ed.). B.G. Teubner, Leipzig (1868-1875)

\section{Author Biography}

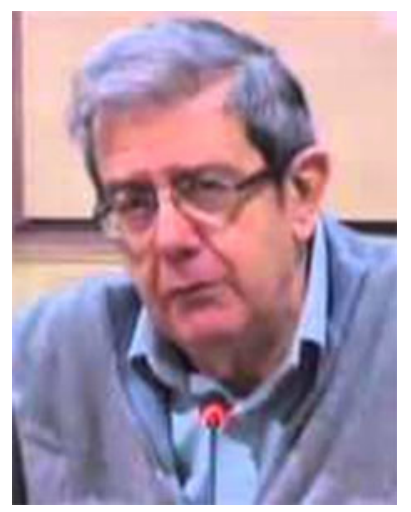

Lucio Russo

teaches history of sciences at Rome's Università 'Tor Vergata'. His research deals with statistical mechanics, calculus of probability and history of science. With regards to this last, he is the author of The Forgotten Revolution (Springer, 2004), Flussi e riflussi (Feltrinelli, 2003), Ingegni minuti (with Emanuela Santoni, Feltrinelli, 2010) and L'America dimenticata (Mondadori Università, 2013). His is also the author of several booklets, such as Segmenti e bastoncini (Feltrinelli, 1998) and La cultura componibile (Liguori, 2008).

\footnotetext{
5 Some scholars, loath to recognise aspects of humour in ancient works, have attempted to attribute the insolvability of the problem to copyists' errors.

${ }^{6}$ In this case as well many scholars are loath to recognise the hoax, which, speaking for myself, appears sufficiently clear.
} 